\title{
Reintroducing Industrial Engineering Students to Manufacturing through Environmental Pertinence
}

El acoplamiento de la manufactura con la pertinencia ambiental como motivador de interés en estudiantes de Ingeniería Industrial

Stephanie Marie Villanueva-Pérez¹, Valerie Odeh-Couvertier², Viviana Vázquez-García ${ }^{3}$, Rocío Isabel Fernández Lafuente ${ }^{4}$, Verónica Díaz Cruz ${ }^{5}$, Zulma Acevedo Figueroa ${ }^{6}$, Jomar Cintrón-Font ${ }^{7}$, Mónica Rivera-Díaz ${ }^{8}$, Rick Méndez ${ }^{9}$, César Rivera-Collazo ${ }^{10}$, Neshmayda Díaz-Llanos ${ }^{11}$, María Femanda Sayago Capelo ${ }^{12}$, Kelvin Gabriel Chávez-Rojas ${ }^{13}$, Esmeralda Niño-Pérez ${ }^{14}$, Yaileen Méndez-Vázquez ${ }^{15}$, Mauricio Cabrera-Ríos ${ }^{16}$

1 University of Puerto Rico at Mayagüez, The Applied Optimization Group, PUERTO RICO https://orcid.org/0000-0002-8124-8483

2University of Puerto Rico at Mayagüez, The Applied Optimization Group, PUERTO RICO https://orcid.org/0000-0001-7840-7132

3University of Puerto Rico at Mayagüez, The Applied Optimization Group, PUERTO RICO https://orcid.org/0000-0002-8791-7254

4 University of Puerto Rico at Mayagüez, The Applied Optimization Group, PUERTO RIco https://orcid.org/0000-0002-7814-259X

5 University of Puerto Rico at Mayagüez, The Applied Optimization Group, PUERTO RICO https://orcid.org/0000-0003-1351-1857

6University of Puerto Rico at Mayagüez, The Applied Optimization Group, PUERTO RICO https://orcid.org/0000-0002-9459-6196

7 University of Puerto Rico at Mayagüez, The Applied Optimization Group, PUERTO RIco https://orcid.org/0000-0002-8005-0280

8 University of Puerto Rico at Mayagüez, The Applied Optimization Group, PUERTO RICO https://orcid.org/0000-0002-1531-5246

9University of Puerto Rico at Mayagüez, The Applied Optimization Group, PUERTO RIco https://orcid.org/0000-0002-3053-5634

10University of Puerto Rico at Mayagüez, The Applied Optimization Group, PUERTO RICO https://orcid.org/0000-0002-5902-2066

11 University of Puerto Rico at Mayagüez, The Applied Optimization Group, PUERTO RICO https://orcid.org/0000-0002-9061-5548

12University of Puerto Rico at Mayagüez, The Applied Optimization Group, PUERTO RIco https://orcid.org/0000-0003-3249-5717

13University of Puerto Rico at Mayagüez, The Applied Optimization Group, PUERTO RICO https://orcid.org/0000-0003-3182-9084

${ }^{14}$ Instituto Tecnológico y de Estudios Superiores de Monterrey, MÉxICO https://orcid.org/0000-0001-5833-9582

15Milwaukee School of Engineering, USA https://orcid.org/0000-0002-2467-2173

${ }^{16}$ University of Puerto Rico at Mayagüez, The Applied Optimization Group, PUERTO RICO https://orcid.org/0000-0002-2845-7147 | mauricio.cabrera1@upr.edu 


\title{
Reintroducing Industrial Engineering Students to Manufacturing through Environmental Pertinence
}

\author{
El acoplamiento de la manufactura con la pertinencia ambiental como motivador de interés en \\ estudiantes de Ingeniería Industrial
}

\begin{abstract}
Manufacturing is a key economic activity. Its know-how and its competitive advantages have shaped the history of humankind. In many Industrial Engineering (IE) programs, however, manufacturing is not taught as related to process know-how, but as systemic integration and management. It is possible to capitalize on the recent $3 \mathrm{D}$ printing technologies to reintroduce IE students to manufacturing principles through prototyping projects. Sparking the interest of IE students, though, can also be achieved through selecting problems of environmental awareness. This work describes a project of self-assemblies developed under the scheme of undergraduate research that makes prototyping a central endeavor with the aim to foster plastic recycling as an end goal.
\end{abstract}

Index terms: 3D Printing, Recycling, Manufacturing Education.

\section{Resumen}

La manufactura es una actividad económica fundamental. El conocimiento experto y las ventajas competitivas que se asocian con ella han dado forma a la historia de la humanidad. Es notorio, sin embargo, que varios programas educativos en Ingeniería Industrial se han alejado poco a poco de conocer más a fondo los procesos de transformación en pos de ver la manufactura a un nivel sistémico y como una actividad puramente de gestión administrativa. El desarrollo relativamente reciente de la tecnología de impresión 3D provee una oportunidad de reintroducir a los estudiantes de Ingeniería Industrial a los principios de procesamiento a través de proyectos que se enfoquen en la creación de prototipos. Sin embargo, para atemperarlo a los tiempos actuales, esta creación de prototipos debe de venir de la mano con un fin como el de tener un impacto positivo en el medio ambiente. Este artículo describe un proyecto de piezas autoensamblables desarolladas a través de un esquema de investigación subgraduada en el que se hizo énfasis en las actividades de manufactura de prototipos como un medio para eventualmente llegar al fin de favorecer el reciclaje de plástico.

Palabras clave: Impresión 3D, Reciclaje, Educación sobre procesos de manufactura.

Recibido 23-03-2020, aceptado 27-08-2020. 


\section{INTRODUCTION}

Manufacturing is a key economic human activity that importantly drives technology and scientific development. Knowing how to manufacture better goods, massively, in less time, with a minimal cost has often decided the survival of countries, the outcomes of wars, and the possibility to move upward in the wellbeing scale. Although Industrial Engineering (IE) was intrinsically related to manufacturing in the past, the versatility of its techniques and its fitness for systemic analysis has taken the discipline to diversify and take a macro view. This often leaves many IE students with little experience in actual manufacturing processes.

A clear opportunity to reacquire acquaintance with manufacturing processes for IE students is the relatively recent development of 3D printing [1]. 3D printing is perhaps the best-known process from additive manufacturing, which implies creating an object adding material in a layer-by-layer fashion. This differs from forming processes, which usually require the use of molds and cores, and from machining processes, which require removing material. An excellent overview in 3D printing technology can be found elsewhere [2].

In order to start reintroducing students to 3D printing, in our case it was necessary to use the flexibility of undergraduate research credit hours. Although the presence of a 3D printer was important to call the attention of students, it was placing importance in the actual application and its effect on the environment what allowed more people to be engaged, especially female students. This way, learning to prototype was tied to having a positive effect through designing for recycling. In short, the idea was to create an endeavor that is both, purposedriven and skill-building. Indeed, this kind of integration has been deemed attractive in other higher education endeavors [3], [4].

In summary, this work describes primarily a technical project that involves the design, prototyping, and iterative improvement of a self-assembly unit intended to be eventually manufactured with recycled PET from water bottles. A key enabler of this project, however, was the organization of undergraduate students across generations to carry it out along with the motivation to keep them engaged. Thus, the narrative involves the development of a hard system along with the soft system that supported its creation. The final results are also twofold: an injection mold ready to be used for production of the self-assembly units and a renewed interest in manufacturing processes in our IE students.

\section{Methodology}

The solution of manufacturing problems involves Engineering savvy, resources, and stick-to-itiviness. Manufacturing systems are considered hard systems, as they can be dealt with precision, mathematical analysis, and technical methods. Marshaling the expertise, the resources, and the follow-through, however, is more akin to a management endeavor, and, therefore falls in the category of soft systems. An effort is here made to describe the development of a hard system supported by a soft system. The methods used in this work will be explained referring to each system separately.

\section{A. The Soft System: Undergraduate Research Scheme}

In our Industrial Engineering program at University of Puerto Rico at Mayagüez, it is possible to use up to six credit hours in undergraduate research as part of the curriculum. These are counted either as professional or free electives, depending on the student's choice. Students were proposed to take undergraduate research in three consecutive semesters with one, two, and three credits respectively. Students who signed up were usually assigned to work in pairs. Although not all students were involved in research for three semesters, it was possible to have continuity with incoming students on each semester. It is also important to note that students from Mechanical Engineering (ME) got involved enthusiastically due to the opportunity to design a part from scratch. 
Students were encouraged to learn to use the 3D printer by using the manual and ready-to-print models downloaded from Thingiverse.com. Those who advanced more rapidly were usually incredibly open to train their peers. The true bottleneck, however, was computer-aided modeling (CAD) of individual parts. This skill is strong in ME students, but not usually in IEs. So, initially, part modeling was left to ME students who then trained IE students.

A critical component for the success of this work had to do with explicitly incorporating the positive potential effect of the project in something important: the environment. The rapid accumulation of plastic waste together with its slow decomposition rate spanning centuries is a problem of global proportions. The fact that the islands of Puerto Rico do not have working plastic recycling centers aggravates the problem locally. Environmental effects are evident when analyzing the deterioration of sealife and the formation of plastic islands in the Caribbean [5]. With this in mind, it was decided to concentrate in -eventually- recycling PET water bottles.

\section{B. The hard system: initial assembly}

In order to design an operation to eventually recycle PET water bottles as a means of mitigation of environmental pollution, the aim of the project was initially set to prototype a piece -through $3 \mathrm{D}$ printing- that could be assembled with others similar to it. These assemblies, depending on the number of units integrating them, would result in different planar pieces that could function as coasters, cutting boards, sink protections, floor covers, or garden stepping stones. The latter instance, the garden stepping stone, was chosen as the target design of this endeavor. An important constraint was that the pieces should self-assemble, as they would in a puzzle. This implied that no fasteners could be used. The idea behind this restriction had to do with keeping the operation convenient for a final user who would not require any other accessory to assemble the units together. These self-assemblies would, in a posterior stage, be fabricated using recycled PET water bottles, as noted previously.

The first parts created in this project are shown in Figure 1 already assembled as a garden stepping stone. A total of 124 units conform the assembly.

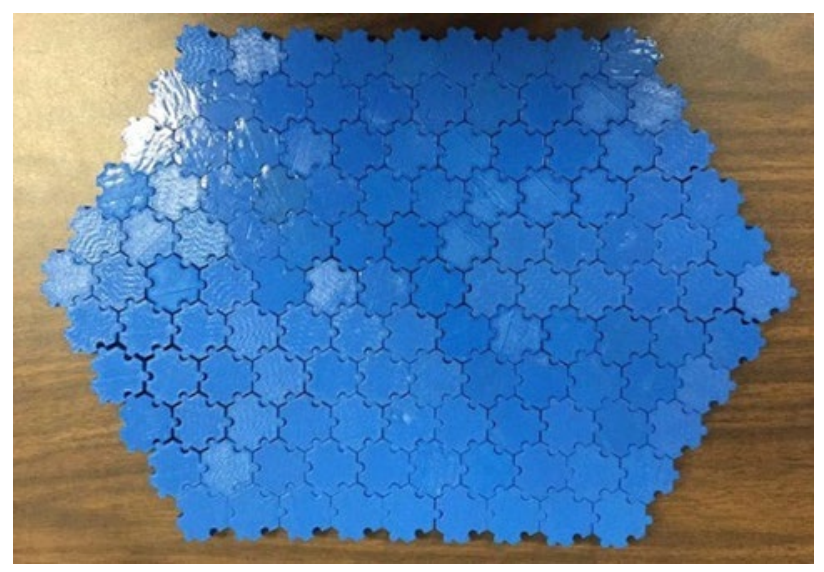

Fig. 1. 124 initial units assembled in a garden stepping stone.

To determine the dimension of the initial self-assembly unit, a formal multiple criteria optimization process was undertaken, as described in [6]. Graphically, final results of this process are shown in Figure 2. The two criteria to be optimized were: mass (minimal) and load (maximal). Three configurations were deemed the best compromises between these two conflicting criteria. Their dimensions are also shown in Figure 2. 

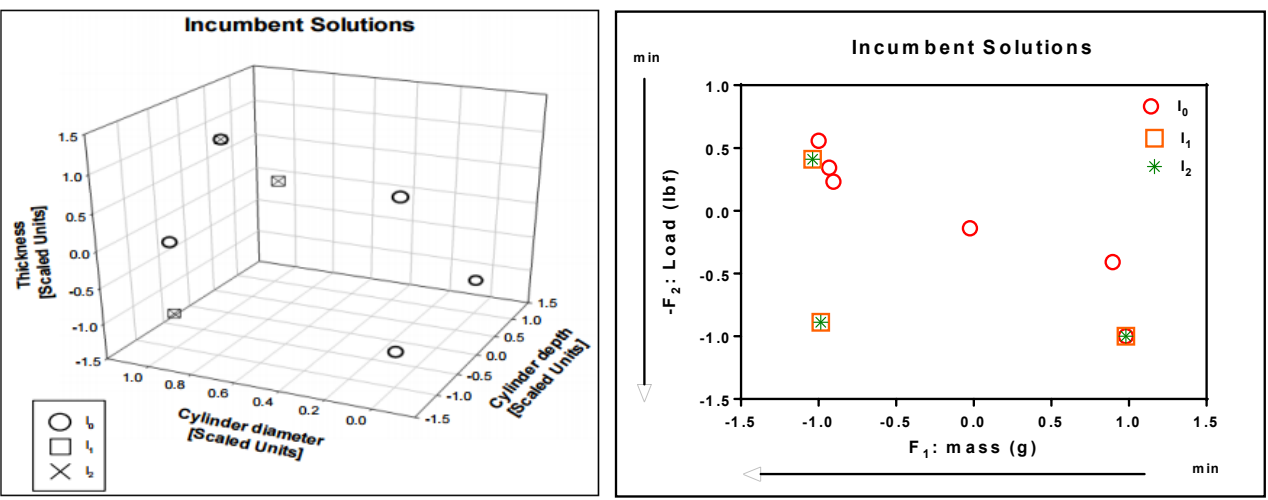

\begin{tabular}{cccccc} 
Assembly ID & $\begin{array}{c}\text { BEST DESIGNS UNDER TWO CRITERIA: MiniMAL MASS AND MAXIMAL LOAD } \\
\text { Thickness }\end{array}$ & $\begin{array}{c}\text { Cylinder diameter } \\
\text { (in) }\end{array}$ & $\begin{array}{c}\text { Cylinder } \\
\text { (in) }\end{array}$ & Mass (g) & Max Load (lbf) \\
\hline 1 & 0.092 & 0.041 & 0.230 & 11.2716 & 139.597 \\
\hline 2 & 0.230 & 0.041 & 0.230 & 11.0938 & 44.333 \\
\hline 5 & 0.161 & 0.041 & 0.460 & 17.8560 & 147.733 \\
\hline
\end{tabular}

Fig. 2. A formal multiple criteria optimization problem was set up to arrive to the best configuration under two criteria: minimal mass and maximal load in a flexural strength test. [6].

\section{The Hard System: scaling up the assembly}

Despite the feasibility of the first assembly, when translating the mass of the individual pieces, it was calculated that a regular bottle of plastic (PET water bottles), would generate between 6 and 8 pieces. A decision was then made to rather keep the ratio of 1 PET bottle to 1 piece. This would further facilitate the transfer from 3D printing prototyping to injection molding, where it was deemed more convenient to have a one-cavity mold as opposed to a multicavity one. Using the average mass of a PET bottle as a guide $(11.75 \mathrm{~g})$, the design was scaled up as illustrated in Figure 3.

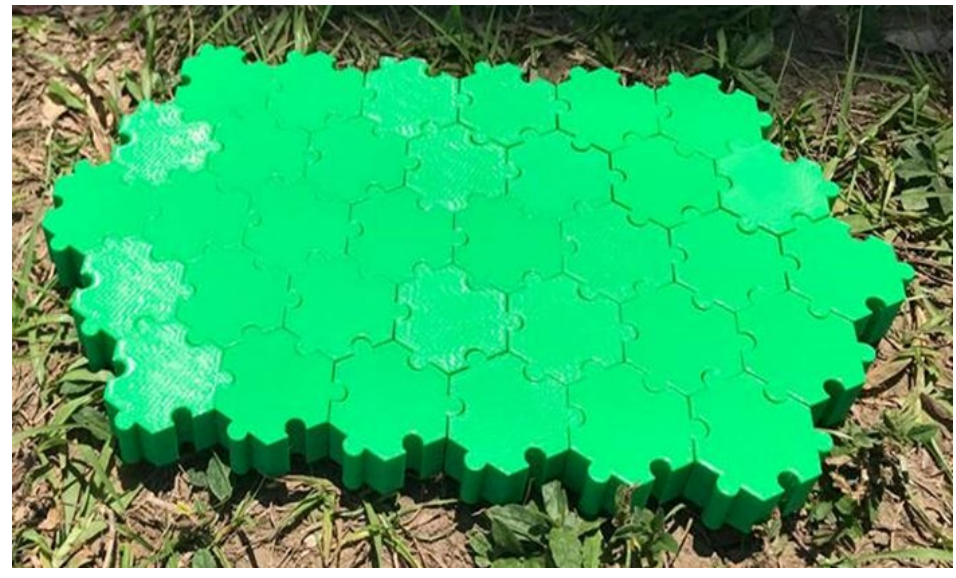

Fig. 3. Scaled up version of the self-assembly using 34 units. 


\section{The Hard System: A first step into the final stage}

The 3D printed prototype led to a geometry that allowed self-assembly and performance. The next challenge in this work required a redesign of the piece that would facilitate injection molding while keeping a similar mass. This meant moving from a targeted solid piece to a thin-walled one that could avoid part distortion due to jetting and short shots. The resulting redesign and the injection mold are shown in Figure 4.

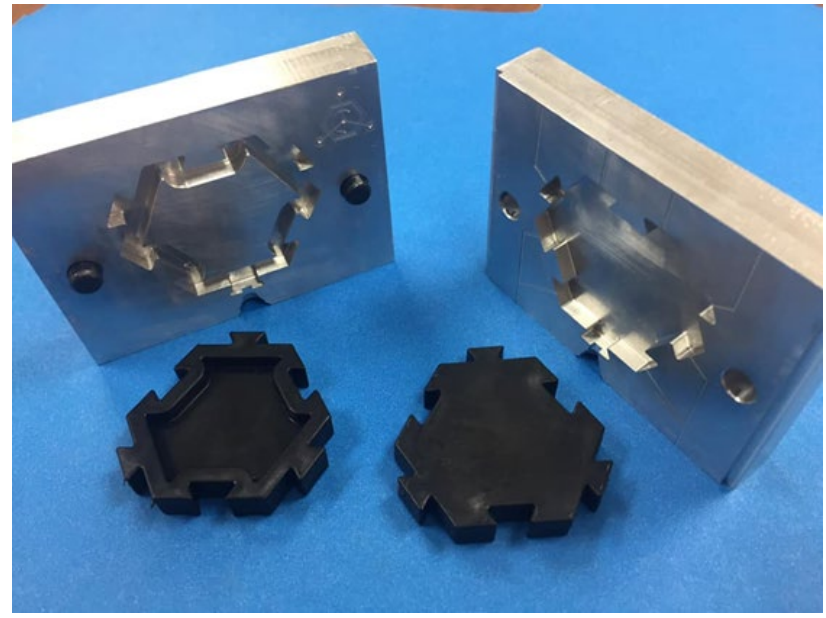

Fig. 4. Self-assembling units redesigned for injection molding and the two halves of the mold.

\section{DISCUSSION}

The progression of the project outlined here has taken roughly 5 years. The initial assembly, as discussed previously, was supported not only by mechanical design and prototyping, but by mathematical optimization. Figure 2 shows the tradeoff that needed to be understood in the self-assembly unit: load bearing could only be achieved at the expense of mass. It also showed which features had an important effect on both criteria, and which did not. Transferring this knowledge to the scaled-up version was important to remain feasible.

Clearly, adjustments through the different design versions of the self-assemblies had to be made, especially as more requirements became apparent. An important one was making sure that the self-assembly could be produced through injection molding. In this sense, the design aspect of this work was faithful to its well-known iterative nature.

This project -along with others of similar nature- has awakened the interest from IE students, and importantly women, in manufacturing processes to support efforts in recycling. In fact, every semester in the last two years, between 15 and 25 students have signed up for undergraduate research credits to get involved in manufacturing projects coupled with significant positive impacts, including recycling, making products for communities with little resources, or supporting humanitarian efforts in disasters. The next stage in this project involves setting up a recycling operation using at least a plastic shredder and an injection-molding machine.

\section{IV.CONCLUSIONS}

It is difficult to overlook how plastics have become an environmental nightmare. Although there are many efforts into alleviating such situation, this work focused on reawakening the interest of IE students in 
manufacturing to marshal an approach to recycling. As it can be seen, the project had to be nurtured through a scheme of undergraduate research and a series of technical iterations that has led to a feasible design. More importantly, the project has been successful in reawakening the interest in manufacturing in our IE students and, in particular, our female students. The effort is going into its fifth year, with the goal to start a recycling operation in the future.

ACKNOWLEDGEMENT

The authors acknowledge the support of the Industrial Engineering Department at UPRM. This work was partially supported by USDA-NIFA Award 2015-38422-24064 sub award 1000000920. BE AWARE Project.

\section{REFERENCES}

[1] T.W. Simpson, C.B. Williams, M. Hripko, "Preparing Industry for Additive Manufacturing and Its Applications: Summary \& Recommendations From a National Science Foundation Workshop," Additive Manufacturing, vol. 13, no. 13, pp. 166-178, Jan., 2017, doi: https://doi.org/10.1016/j.addma.2016.08.002

[2] J. Kietzmann, L. Pitt, P.Berthon "Disruptions, decisions, and destinations: Enter the age of 3-D printing and additive manufacturing", Business Horizons, vol. 58, no. 2, pp. 209-215, doi: https://doi.org/10.1016/j.bushor.2014.11.005

[3] M. E. Zepeda-Hurtado, L. Campos-Monroy, M. Cuéllar-Orozco "El Proyecto Aula, metodología para el desarrollo de competencias profesionales", Cientifica, vol. 21, no. 2, pp. 135-142, julio-diciembre 2017, available: http://www.cientifica.esimez.ipn.mx/manuscritos/V21N2_135_142.pdf

[4] J. García-Ortega, J. Bernardo Parra-Victorino, M.L. Santos-Palacios, G. Zarza-Arronte "Proveedores de tecnología,spin-off universitarios a partir de los Laboratorios de Innovación Tecnológicos," Científica, vol.18, no. 1, pp. 31-37, enero-marzo 2014, available: http://www.cientifica.esimez.ipn.mx/manuscritos/completos/VOL18_NUM1_2014.pdf

[5] J.A. Ivar do Sul, M.F. Costa "Marine debris review for Latin America and the Wider Caribbean Region: From the 1970s until now, and where do we go from here?," Marine Pollution Bulletin, vol. 54, no. 8, pp. 1087-1104, agosto, 2007, available: https://www.ncbi.nlm.nih.gov/pubmed/17624374

[6] E. Niño Pérez, C.A. Rivera-Collazo, M. Cabrera-Ríos, Y. M. Méndez-Vázquez, "Iterative multicriteria simulation and prototyping optimization in manufacturing," en 2017 Winter Simulation Conference (WSC), Las Vegas, EE.UU., 3-6 diciembre, 2017, available: https://ieeexplore.ieee.org/document/8247809 